\title{
Genotyping of white spot syndrome virus (WSSV) geographical isolates from Brazil and comparison to other isolates from the Americas
}

\author{
Isabel C. Muller ${ }^{1,2}$, Thales P. D. Andrade ${ }^{1}$, Kathy F. J. Tang-Nelson ${ }^{1}$, \\ Maria R. F. Marques ${ }^{2, *}$, Donald V. Lightner ${ }^{1}$ \\ ${ }^{1}$ Department of Veterinary Science and Microbiology, University of Arizona, 1117 E. Lowell, Tucson, Arizona 85721, USA \\ ${ }^{2}$ Departamento de Bioquímica, ССB, Universidade Federal de Santa Catarina, Campus Universitário, Trindade, \\ Florianópolis, Santa Catarina 88049-970, Brazil
}

\begin{abstract}
White spot syndrome virus (WSSV) is a viral pathogen that has caused significant economic losses in shrimp farming. Variable-number tandem repeats (VNTRs) (open reading frame [ORF] 94, 125 and 75), a large deletion (ORF 23/24) and a transposase were proposed as molecular markers for genotyping. WSSV-infected shrimp Litopenaeus vannamei were collected in 2 Brazilian regions (Santa Catarina and Bahia) from 2005 to 2008. DNA was extracted and PCR of the variable regions was performed, followed by sequencing. All Santa Catarina samples showed the same number of repeats for the minisatellites analyzed. Bahia samples showed a different pattern for the regions, indicating that there are at least 2 different WSSV genotypes in Brazil. Both Brazilian isolates have an 11453 bp deletion in ORF 23/24 when compared with WSSV-TW (Taiwan), which has the full sequence for this locus. The Brazilian WSSV isolates were compared with WSSV isolates from other countries in the Americas (USA, Panama, Honduras, Mexico and Nicaragua); the repeat number patterns for the 3 VNTR regions analyzed were different between the Brazilian isolates and the other western-hemisphere isolates. This may be due to mutations in WSSV after its introduction into the different countries. Our results also show that WSSV found in Bahia and Santa Catarina very likely originated from different sources of contamination.
\end{abstract}

KEY WORDS: WSSV · White spot syndrome virus · Genotyping • Variable-number tandem repeats · Litopenaeus vannamei

Resale or republication not permitted without written consent of the publisher

\section{INTRODUCTION}

White spot syndrome virus (WSSV) is a viral pathogen that has caused great losses in the shrimp farming industry since 1993 (Lo et al. 1996, He et al. 2005). Since its first occurrence in Fujian, China during 1991 to 1992 (Cai et al. 1995, Flegel 1997), the virus has spread rapidly through Asia (Inouye et al. 1994, Lo et al. 1999). The virus was found in the Americas for the first time in the USA in 1995 (Nunan \& Lightner 1997) and later identified in several other countries in the western hemisphere (Mexico, Guatemala, Honduras, Nicaragua, Panama, Ecuador and Colombia) (INFOFISH 1999).
The geographic translocation of WSSV has also expanded to marine shrimp farms located in the south (Santa Catarina State) and northeast (Ceará and Bahia State) of Brazil (OIE 2005a,b, D. V. Lightner unpubl.). From January 2005 to 2008, WSSV caused significant economic losses in Santa Catarina State. Before the disease appeared in Santa Catarina State, 100 farms produced $4100 \mathrm{t}$ of shrimp in total, but in 2006 and 2007, only 3 operating farms were able to produce $59 \mathrm{t}$ in total (Mello \& Farias 2007). A WSSV outbreak was also reported on 1 farm in Ceará State (March 2005); however, no more outbreaks have been documented in Ceará since that time. In November 2008, a WSSV outbreak was also confirmed in farms located in Bahia 
State, where shrimp survival of $5 \%$ was reported in the affected ponds. There is no information or knowledge concerning the introduction of the disease into Brazil, since the importation of crustaceans has been forbidden since 1999.

WSSV is a bacilliform virus with a rod-shaped nucleocapsid surrounded by a trilaminar envelope and has a unique tail-like appendage at one end (Durand et al. 1997, Nadala et al. 1998). The virus has a large double-stranded circular genome of $\sim 300 \mathrm{~kb}$ (van Hulten et al. 2001, Yang et al. 2001). The WSSV genome encodes 184 putative open reading frames (ORFs), most of them of unknown function. Only 11 ORFs have homologs in public databases, mainly representing genes encoding enzymes for nucleotide metabolism, DNA replication and protein modification (van Hulten et al. 2001).

Geographic isolates of WSSV from Asia and the Americas that have been compared are very similar in morphology and protein profile and show little difference in restriction fragment length polymorphism (RFLP) pattern (Nadala \& Loh 1998, Lo et al. 1999, Wang et al. 2000, Marks et al. 2004). Marks et al. (2004) performed a comparison between 3 completely sequenced WSSV isolates, Thailand (TH), China (CN) and Taiwan (TW), and found a nucleotide similarity of $99.2 \%$. The differences found by these authors include: a large deletion region (ORF 23/24) of $\sim 13.2 \mathrm{~kb}$ in WSSV-TH and $\sim 1.2 \mathrm{~kb}$ in the WSSV-CN genome relative to WSSV-TW; a variable region prone to recombination (ORF 14/15); a transposase sequence present only in WSSV-TW; a variation in the number of repeat units (RUs) within homologous and direct repeats; and single-nucleotide mutations involving deletion, insertion or single-nucleotide polymorphisms (SNPs). The variations associated with ORF 23/24 and ORF 14/15 were reported to be useful in identifying evolutionary changes in WSSV (Marks et al. 2005). The variablenumber tandem repeats (VNTRs) associated with 3 minisatellites (RU size 7 to $100 \mathrm{bp}$ ), ORFs 94,75 and 125, have been suggested as potential markers for epidemiological studies (Wongteerasupaya et al. 2003, Dieu et al. 2004, Marks et al. 2004, Shekar et al. 2005).

Some genotyping studies have been performed to test the efficacy of these markers (Wongteerasupaya et al. 2003, Marks et al. 2005, Pradeep et al. 2008). The majority of these studies were performed in Asian countries such as Vietnam, India and Thailand. As far as we know, the only studies performed with isolates from the Americas used RFLP (Lo et al. 1999, Wang et al. 2000) to compare samples from different regions, but the authors did not find many differences.

The aims of the present study were to genotype 4 Brazilian WSSV isolates and to compare the results to those obtained for 7 other WSSV isolates originating from other countries in the Americas using ORFs 94, 75 and 125, ORF 23/24 and a putative transposase as markers. The results obtained will help to determine whether the different outbreaks that occurred in Brazil and in other western-hemisphere countries were caused by the same or different genotypes of WSSV.

\section{MATERIALS AND METHODS}

Shrimp sampling. The WSSV-infected shrimp (Litopenaeus vannamei) samples used in this study were collected in 2 Brazilian regions during different time periods (Table 1). Santa Catarina is located in the south and was the first Brazilian state where WSSV was reported (OIE 2005a), while Bahia is located in the northeast, $2600 \mathrm{~km}$ from Santa Catarina. The Santa Catarina samples used in the present study were collected from affected ponds from January 2005 until November 2008. The Bahia samples and those originating from other countries were contributed by the laboratory of D. V. Lightner at the University of Arizona, USA (Table 1). The samples consisted of tissues originating from shrimp that had displayed clinical signs of WSSV infection and were either preserved in $95 \%$ ethanol or immediately frozen in liquid nitrogen and then stored at $-80^{\circ} \mathrm{C}$. In total, 11 different WSSVinfected samples were analyzed: 3 originating from Santa Catarina, 1 from Bahia and 7 from other locations in the Americas.

WSSV challenge. Since the samples from south and north Santa Catarina had moderate viral loads, a WSSV inoculum was prepared from frozen shrimp to

Table 1. Source, date and number of white spot syndrome virus (WSSV)infected shrimp samples. na: not available

\begin{tabular}{|c|c|c|c|c|}
\hline Country & Region & Year & $\begin{array}{c}\text { No. of } \\
\text { ponds analyzed }\end{array}$ & $\begin{array}{l}\text { No. of shrimp } \\
\text { collected }\end{array}$ \\
\hline USA & Texas & 1997 & na & na \\
\hline USA & South Carolina & 1997 & na & na \\
\hline Panama & West coast & 1999 & na & na \\
\hline Honduras & Gulf of Fonseca & 1999 & na & na \\
\hline USA & Hawaii & 2004 & na & na \\
\hline Brazil (south) & Santa Catarina & 2005 & 3 & 15 \\
\hline Brazil (south) & Santa Catarina & 2007 & 2 & 10 \\
\hline Brazil (south) & Santa Catarina & 2008 & 2 & 25 \\
\hline Brazil (northeast) & Bahia & 2008 & na & na \\
\hline Nicaragua & Gulf of Fonseca & 2008 & na & na \\
\hline Mexico & Sonora & 2008 & na & na \\
\hline
\end{tabular}


generate stronger WSSV-positive samples and used to challenge specific pathogen-free (SPF) Litopenaeus vannamei ( 3 g) Kona stock (Lightner 2005) obtained from the Oceanic Institute (Oahu, Hawaii). Frozen WSSV-infected pleopods were thawed and homogenized in TN buffer (20 mM Tris- $\mathrm{HCl}, 400 \mathrm{mM} \mathrm{NaCl}$, $\mathrm{pH}$ 7.4). The homogenate was centrifuged at $2500 \mathrm{rpm}$ for $20 \mathrm{~min}$, the supernatant obtained was centrifuged again at $5000 \mathrm{rpm}$ for $20 \mathrm{~min}$, and the resultant supernatant was diluted $1: 20$ in $2 \% \mathrm{NaCl}$. Experimental infection was induced by injecting $0.1 \mathrm{ml}$ of the suspension into the abdomen through the fourth tergal plate and into the third abdominal segment. The WSSV-infected shrimp were examined daily and all dead and moribund shrimp were removed and frozen. The experiment was terminated $72 \mathrm{~h}$ post-injection.

DNA extraction. DNA was extracted from 25 to $50 \mathrm{mg}$ of pleopods from each of the 11 WSSV sample groups using the High Pure PCR Template Preparation Kit (Roche) according to the manufacturer's instructions.

PCR for WSSV detection. WSSV was identified in the samples by 2-step PCR using the primers described by Lo et al. (1996). All PCR reactions were performed with individual samples. Each reaction mixture consisted of $1 \times$ Taq buffer, $200 \mu \mathrm{M}$ of each dNTP, $2 \mathrm{mM}$ $\mathrm{MgCl}_{2}, 200 \mathrm{pM}$ of each primer, and $0.63 \mathrm{U}$ Taq enzyme (Fermentas). DNA was amplified by an initial step at $94^{\circ} \mathrm{C}$ for $2 \mathrm{~min}$, followed by 30 cycles of $94^{\circ} \mathrm{C}$ for $30 \mathrm{~s}$, $62^{\circ} \mathrm{C}$ for $30 \mathrm{~s}$, and $72^{\circ} \mathrm{C}$ for $30 \mathrm{~s}$, with a final extension at $72^{\circ} \mathrm{C}$ for $2 \mathrm{~min}$. All PCR products were analyzed on $1.5 \%$ agarose gels containing $0.5 \mu \mathrm{g} \mathrm{l}^{-1}$ ethidium bromide, and a $1 \mathrm{~kb}$ DNA ladder was used as a marker.

Analysis of VNTRs. Three minisatellite regions were analyzed by PCR: ORF 94 (54 bp repeats), ORF 125 (69 bp repeat) and ORF 75 (45 and 102 bp repeats). Specific published primers for each gene were used (Dieu et al. 2004, Pradeep et al. 2008). The cycling conditions are given in Table 2.

Analysis of the variable region ORF 23/24. Samples were analyzed for the deletion region ORF 23/24 using the primers of Pradeep et al. (2008) and according to the conditions stated in Table 2 .
Amplification of a transposase sequence. The presence of a transposase gene was analyzed by PCR using the primers of Dieu et al. (2004) and the conditions summarized in Table 2.

Determination of the number of repeats. The number of RUs present in ORF 94 was calculated as [amplicon size - $(171+12)] / 54$, and in ORF 125 as (amplicon size $+35-92) / 69$ (Pradeep et al. 2008). In the case of ORF 75, which has repeats of different sizes, the amplicon size was used for the comparisons.

Sequencing of PCR products and sequence analysis. PCR products were purified with the QIAquick PCR purification kit (Qiagen) and sequenced at the University of Arizona sequencing facility using an automatic DNA sequencer (3730xl DNA analyzer, Applied Biosystems). The sequences obtained were compared with WSSV genomes stored in GenBank and were analyzed with BioEdit version 7.0.9.0 (Hall 1999). The presence and number of tandem repeats were analyzed with the Tandem Repeats Finder (TRF) program (Benson 1999).

Comparison with samples from other countries in the Americas. After the Brazilian WSSV isolates had been genotyped, they were compared with other WSSV geographic isolates originating from different countries in the Americas (Table 1). The VNTRs (ORFs 94,75 and 125) were used for comparing the isolates.

\section{RESULTS}

\section{ORF 94}

The sizes of the repeat types found are summarized in Table 3 and ranged from 4 to 19 repeats. All samples tested gave amplicons for the ORF 94 region (Fig. 1). The Brazilian samples from Santa Catarina had amplicons of similar sizes (around $1000 \mathrm{bp}$ ), while the Bahia sample produced a smaller amplicon (417 bp). Samples were sequenced and confirmed as ORF 94, with 99\% similarity with the WSSV isolate TH-96-II ORF94 (GenBank accession no. AY864669.1). The number of

Table 2. PCR cycling conditions. Extension: extension conditions for each round; WSSV-TW: WSSV isolate from Taiwan; WSSV-CN: WSSV isolate from China

\begin{tabular}{|c|c|c|c|c|c|c|c|}
\hline \multirow{2}{*}{ Primer } & \multirow[b]{2}{*}{$\begin{array}{c}\text { Initial } \\
\text { denaturation }\end{array}$} & \multirow{2}{*}{\multicolumn{2}{|c|}{$\begin{array}{l}\text { Cycling conditions } \\
\text { Denaturation Annealing }\end{array}$}} & \multirow[b]{2}{*}{ Extension } & \multirow[b]{2}{*}{$\begin{array}{l}\text { No. of } \\
\text { cycles }\end{array}$} & \multirow{2}{*}{$\begin{array}{l}\text { Product size } \\
\text { (bp) }\end{array}$} & \multirow{2}{*}{ Source } \\
\hline & & & & & & & \\
\hline ORF 94 & $85^{\circ} \mathrm{C}, 5 \mathrm{~min}$ & $95^{\circ} \mathrm{C}, 20 \mathrm{~s}$ & $60^{\circ} \mathrm{C}, 20 \mathrm{~s}$ & $72^{\circ} \mathrm{C}, 1 \min 15 \mathrm{~s}$ & 40 & Variable & Pradeep et al. (2008) \\
\hline ORF 75 & $95^{\circ} \mathrm{C}, 1 \mathrm{~min}$ & $95^{\circ} \mathrm{C}, 30 \mathrm{~s}$ & $49^{\circ} \mathrm{C}, 20 \mathrm{~s}$ & $72^{\circ} \mathrm{C}, 1 \mathrm{~min} 20 \mathrm{~s}$ & 36 & Variable & Pradeep et al. (2008) \\
\hline ORF 125 & $95^{\circ} \mathrm{C}, 1 \mathrm{~min}$ & $95^{\circ} \mathrm{C}, 30 \mathrm{~s}$ & $52^{\circ} \mathrm{C}, 20 \mathrm{~s}$ & $72^{\circ} \mathrm{C}, 1 \mathrm{~min} 40 \mathrm{~s}$ & 40 & Variable & Dieu et al. (2004) \\
\hline Transposase & $95^{\circ} \mathrm{C}, 1 \mathrm{~min}$ & $95^{\circ} \mathrm{C}, 30 \mathrm{~s}$ & $55^{\circ} \mathrm{C}, 1 \mathrm{~min}$ & $72^{\circ} \mathrm{C}, 4 \mathrm{~min}$ & 35 & $\begin{array}{l}1489 \text { (WSSV-TW) } \\
151 \text { (WSSV-CN) }\end{array}$ & Dieu et al. (2004) \\
\hline ORF 23/24 & $95^{\circ} \mathrm{C}, 15 \mathrm{~min}$ & $94^{\circ} \mathrm{C}, 20 \mathrm{~s}$ & $50^{\circ} \mathrm{C}, 1 \mathrm{~min}$ & $72^{\circ} \mathrm{C}, 8 \mathrm{~min}$ & 35 & Variable & Pradeep et al. (2008) \\
\hline
\end{tabular}


Table 3. Number of tandem repeat units (RUs) found for ORFs 94, 125 and 75 in WSSV-infected shrimp samples originating from Brazil $(n=4)$ and other countries in the Americas $(n=7)$. nd: not detected. For regions see Table 1

\begin{tabular}{|c|c|c|c|c|c|c|}
\hline \multirow[t]{2}{*}{ Region } & \multicolumn{2}{|c|}{ ORF 94} & \multicolumn{2}{|c|}{ ORF 125} & \multicolumn{2}{|c|}{ ORF 75} \\
\hline & $\begin{array}{l}\text { Amplicon size } \\
\text { (bp) }\end{array}$ & $\begin{array}{l}\text { No. of } \\
\text { RUs }\end{array}$ & $\begin{array}{l}\text { Amplicon size } \\
\text { (bp) }\end{array}$ & $\begin{array}{l}\text { No. of } \\
\text { RUs }\end{array}$ & $\begin{array}{l}\text { Amplicon size } \\
\text { (bp) }\end{array}$ & $\begin{array}{l}\text { No. of } \\
\text { RUs }\end{array}$ \\
\hline Texas & 480 & 5 & 767 & 10 & 1171 & 14 \\
\hline South Carolina & 460 & 5 & 767 & 10 & nd & nd \\
\hline Panama & 847 & 12 & 853 & 11 & 1112 & 15 \\
\hline Honduras & 896 & 13 & 871 & 11 & 1171 & 15 \\
\hline Hawaii & 627 & 8 & 826 & 11 & 492 & 6 \\
\hline Santa Catarina, 2005 & 1100 & 16 & 684 & 8 & 786 & 10 \\
\hline Santa Catarina, 2007 & 1002 & 16 & 659 & 8 & 783 & 10 \\
\hline Santa Catarina, 2008 & 1015 & 16 & 659 & 8 & 784 & 10 \\
\hline Bahia & 417 & 4 & 728 & 9 & 928 & 11 \\
\hline Nicaragua & 967 & 14 & 662 & 8 & 663 & 8 \\
\hline Mexico & 1242 & 19 & 559 & 7 & 1084 & 14 \\
\hline
\end{tabular}

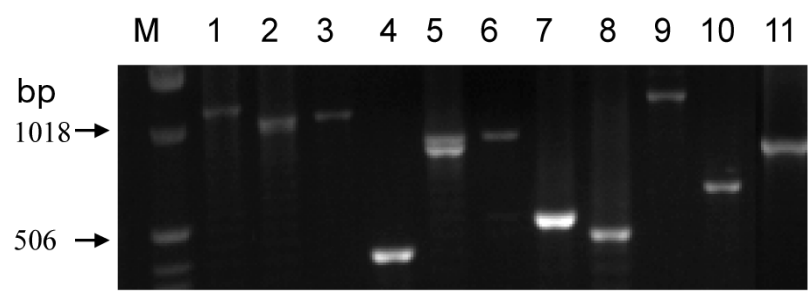

Fig. 1. PCR amplification products from WSSV ORF 94. Lanes: M: 1 kb DNA ladder; 1: Santa Catarina, 2008; 2: Santa Catarina, 2007; 3: Santa Catarina, 2005; 4: Bahia; 5: Panama; 6: Honduras; 7: Texas; 8: South Carolina; 9: Mexico; 10: Hawaii; 11: Nicaragua. For regions see Table 1

repeats found in every single specimen in each batch of Santa Catarina samples was 16 repeats of $54 \mathrm{bp}$ each, while the Bahia sample had 4 repeats (Table 3 ). The Texas and South Carolina samples were found to have 5 repeats, Hawaii had 8, Panama had 12, Honduras had 13, Nicaragua had 14 and Mexico 19 repeats.

The SNPs of the Brazilian WSSV isolates were also compared. Although the Santa Catarina samples were found to have the same number of repeats, they differed in the nucleotide pattern at position 48 (Table 4).

\section{ORF 125}

All samples gave amplicons for the ORF 125 region (Fig. 2). The number of repeats ranged from 7 to 11 (Table 3). The Santa Catarina samples were between 659 and $684 \mathrm{bp}$, while the Bahia sample had a $728 \mathrm{bp}$ amplicon. After sequencing, the amplicons were confirmed as ORF 125, with $99 \%$ similarity with the WSSV isolate TH-96-II ORF125 (GenBank accession no. AY864770.1). The number of repeats found in all Santa Catarina samples was 8 and the Bahia isolate had 9 (Table 3). Mexico had 7 repeats, Nicaragua had 8, Texas and South Carolina had 10 each, and Panama, Honduras and Hawaii had 11 each.

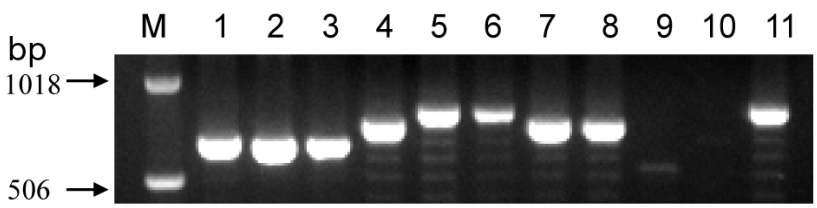

Fig. 2. PCR amplification products from WSSV ORF 125. Lanes: M: 1 kb DNA ladder; 1: Santa Catarina, 2008; 2: Santa Catarina, 2007; 3: Santa Catarina, 2005; 4: Bahia; 5: Panama; 6: Honduras; 7: Texas; 8: South Carolina; 9: Mexico; 10: Nicaragua; 11: Hawaii. For regions see Table 1

Table 4. Genotype of the single-nucleotide polymorphism (SNP) of each repeat unit (RU) within ORF 94 in Brazilian WSSVinfected shrimp samples. G: guanine; T: thymine; na: not applicable

\begin{tabular}{|c|c|c|c|c|c|c|c|c|c|c|c|c|c|c|c|c|c|}
\hline Region & $\begin{array}{c}\text { No. } \\
\text { of RUs }\end{array}$ & 1 & 2 & 3 & 4 & 5 & 6 & 7 & 8 & 9 & 10 & 11 & 12 & 13 & 14 & 15 & 16 \\
\hline Santa Catarina, 2005 & 16 & $\mathrm{~T}$ & $\mathrm{G}$ & $\mathrm{T}$ & $\mathrm{T}$ & $\mathrm{G}$ & $\mathrm{T}$ & $\mathrm{G}$ & $\mathrm{G}$ & $\mathrm{G}$ & $\mathrm{G}$ & $\mathrm{T}$ & $\mathrm{G}$ & $\mathrm{G}$ & $\mathrm{G}$ & $\mathrm{G}$ & $\mathrm{G}$ \\
\hline Santa Catarina, 2007 & 16 & $\mathrm{~T}$ & $\mathrm{G}$ & $\mathrm{T}$ & $\mathrm{T}$ & $\mathrm{T}$ & $\mathrm{T}$ & $\mathrm{T}$ & $\mathrm{T}$ & $\mathrm{T}$ & $\mathrm{T}$ & $\mathrm{T}$ & $\mathrm{T}$ & $\mathrm{G}$ & $\mathrm{G}$ & $\mathrm{T}$ & $\mathrm{G}$ \\
\hline Santa Catarina, 2008 & 16 & $\mathrm{~T}$ & $\mathrm{G}$ & $\mathrm{T}$ & $\mathrm{G}$ & $\mathrm{T}$ & $\mathrm{T}$ & $\mathrm{T}$ & $\mathrm{T}$ & $\mathrm{T}$ & $\mathrm{T}$ & $\mathrm{T}$ & $\mathrm{T}$ & $\mathrm{T}$ & $\mathrm{T}$ & $\mathrm{T}$ & $\mathrm{T}$ \\
\hline Bahia, 2008 & 4 & $\mathrm{~T}$ & $\mathrm{G}$ & $\mathrm{G}$ & $\mathrm{G}$ & na & na & na & na & na & na & na & na & na & na & na & na \\
\hline
\end{tabular}




\section{ORF 75}

The sizes of the PCR products from ORF 75 ranged from 489 to $1171 \mathrm{bp}$ (Fig. 3) and the number of repeats ranged from 6 to 15 (Table 3). The Santa Catarina samples had amplicons of similar sizes (around $780 \mathrm{bp}$ ) and after sequencing the fragments, 10 repeats were found (Table 3). Two sizes of repeats were found, 45 and $102 \mathrm{bp}$ (Table 5) and the pattern of the repeats was 45 , $102,45 \times 2,102,45 \times 2,102$, and $45 \times 2$. The Bahia sample amplicon was larger (828 bp) and, following sequencing and analysis, 11 repeats were found. The pattern of repeats was $45,102,45 \times 3,102,45 \times 2,102$, and $45 \times 2$. The fragments had $100 \%$ similarity with the WSSV isolate TH-96-II ORF75 (GenBank accession no. AY864668.1). The Texas and Mexico samples were found to have 14 repeats, Hawaii had 6 repeats, Panama and Honduras had 15 and Nicaragua had 8. Only the South Carolina sample did not produce a product for this region. Both the Panama and Honduras samples had the same repeat pattern, while the Texas and Mexico samples had different repeat patterns

\section{Variable region ORF 23/24}

After sequencing, the products were confirmed as part of ORF 23/24 (Fig. 4). The sequence alignment

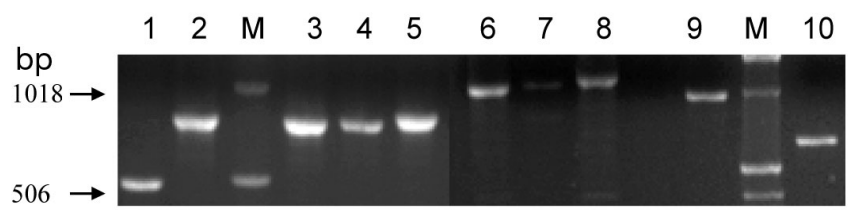

Fig. 3. PCR amplification products from WSSV ORF 75. Lanes: M: 1 kb DNA ladder; 1: Hawaii; 2: Santa Catarina, 2008; 3: Santa Catarina, 2007; 4: Santa Catarina, 2005; 5: Bahia; 6: Panama; 7: Honduras; 8: Texas; 9: Mexico; 10: Nicaragua. For regions see Table 1 with WSSV-TW was from positions 2110 to 2719, after which a deletion of $11453 \mathrm{bp}$ was observed, followed by an alignment from positions 14172 to 15990 . The deletion was the same size in the Santa Catarina and Bahia samples.

\section{Transposase}

A putative transposase is encoded by WSSV-TW. However, this transposase is not found in WSSV-CN or WSSV-TH. When the transposase was present, the primers used in the present study produced an amplicon of around $1330 \mathrm{bp}$, and when the sequence was absent, the amplicon produced was $150 \mathrm{bp}$. All samples analyzed in the present study produced a $150 \mathrm{bp}$ amplicon (Fig. 5), indicating that Brazilian WSSV isolates did not have this transposase.

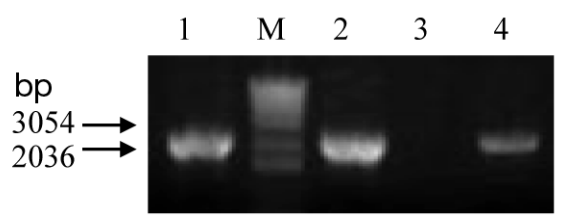

Fig. 4. PCR amplification products from WSSV ORF 23/24 Lanes: M: 1 kb DNA ladder; 1: Santa Catarina, 2008; 2: Santa Catarina, 2007; 3: Santa Catarina, 2005; 4: Bahia

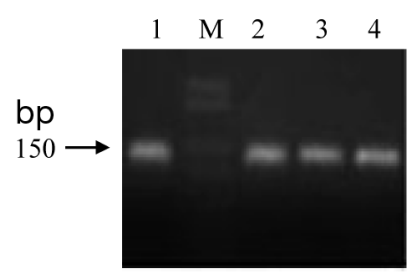

Fig. 5. PCR amplification products from WSSV transposase Lanes: M: 1 kb DNA ladder; 1: Santa Catarina, 2008; 2: Santa Catarina, 2007; 3: Santa Catarina, 2005; 4: Bahia

Table 5. Number of tandem repeat units (RUs) found for ORF 75 and position of the 45 and 102 bp repeats in WSSV-infected shrimp samples from Brazil and other countries in the Americas. Note: the South Carolina sample did not produce an amplicon. For regions see Table 1. na: not applicable

\begin{tabular}{|c|c|c|c|c|c|c|c|c|c|c|}
\hline \multirow{2}{*}{ Region } & \multirow{2}{*}{$\begin{array}{l}\text { No. of } \\
\text { RUs }\end{array}$} & \multirow[b]{2}{*}{1} & \multirow[b]{2}{*}{2} & \multirow[b]{2}{*}{3} & \multicolumn{3}{|c|}{ Position of 45 and $102 \mathrm{bp}$ RUs } & \multirow[b]{2}{*}{7} & \multirow[b]{2}{*}{8} & \multirow[b]{2}{*}{9} \\
\hline & & & & & 4 & 5 & 6 & & & \\
\hline Texas & 14 & 45 & 102 & $45 \times 4$ & 102 & $45 \times 4$ & 102 & $45 \times 2$ & na & na \\
\hline Panama & 15 & 45 & 102 & $45 \times 4$ & 102 & $45 \times 2$ & 102 & $45 \times 2$ & 102 & $45 \times 2$ \\
\hline Honduras & 15 & 45 & 102 & $45 \times 4$ & 102 & $45 \times 2$ & 102 & $45 \times 2$ & 102 & $45 \times 2$ \\
\hline Hawaii & 6 & $45 \times 3$ & 102 & $45 \times 2$ & na & na & na & na & na & na \\
\hline $\begin{array}{l}\text { Santa Catarina, 2005, } \\
\text { 2007, } 2008\end{array}$ & 10 & 45 & 102 & $45 \times 2$ & 102 & $45 \times 2$ & 102 & $45 \times 2$ & na & na \\
\hline Bahia & 11 & 45 & 102 & $45 \times 3$ & 102 & $45 \times 2$ & 102 & $45 \times 2$ & na & na \\
\hline Nicaragua & 8 & 45 & 102 & $45 \times 2$ & 102 & $45 \times 3$ & na & na & na & na \\
\hline Mexico & 14 & 45 & 102 & $45 \times 6$ & 102 & $45 \times 2$ & 102 & $45 \times 2$ & na & na \\
\hline
\end{tabular}




\section{DISCUSSION}

WSSV-infected shrimp samples from 2 Brazilian regions were analyzed and compared to other WSSV geographic isolates from the Americas using the genetic markers proposed for WSSV. All samples from southern Brazil showed the same pattern for the VNTR regions analyzed. The Santa Catarina samples used in the present study were from the first outbreak in 2005 and from later outbreaks (2007 and 2008). However, differences in SNP at position 48 of the ORF 94 repeats were found. In all WSSV isolates characterized so far, ORF 94 has a SNP at position 48 (either guanine or thymine) (Dieu et al. 2004). This difference in SNPs was also found within WSSV isolates from Vietnam, India and Thailand (Wongteerasupaya et al. 2003, Dieu et al. 2004, Pradeep et al. 2008). Apparently, the shrimp were infected by the same type of WSSV, but genomic changes have occurred in the virus since its introduction into Santa Catarina. According to Waikhom et al. (2006), the passage of the virus through different hosts can induce a genomic alteration and alters the pathogenicity of the virus.

The Bahia sample showed a completely different pattern for the 3 genetic markers analyzed, indicating that this WSSV is different from the Santa Catarina isolate. This difference may be due to several reasons. The WSSV isolates found in Bahia and Santa Catarina may have originated from different countries and/or been introduced into Brazil through different vectors. However, it is not clear how the virus was introduced into Brazil. According to Seiffert et al. (2005), the virus could have been introduced before the prohibition of shrimp imports and was latent until the occurrence of the outbreaks. According to the same authors, another possible mode of WSSV introduction is marine currents from Uruguay, since this country processes fish from Ecuador. The virus could also have been introduced by ballast water or illegal importation of live postlarvae (PL) (Baumgartner et al. 2009). Another possible explanation for the differences found between the WSSV isolates from Santa Catarina and Bahia is the occurrence of genomic mutations resulting from the adaptation of the virus to different environmental conditions (Waikhom et al. 2006).

After the Brazilian samples had been characterized, they were compared with WSSV from other countries in the Americas. The number of repeats found for ORF 94 in the present study ranged from 4 to 19 . This result is in agreement with previous studies, where the lowest number of repeats was 4 (Hoa et al. 2005) and the highest was 20 (Wongteerasupaya et al. 2003).

In the present study we did not find particular repeat type dominance; however, there was a dominance of samples with $>9$ repeats. All samples from the Ameri- cas, with the exception of those from the USA, had $>9$ repeats in ORF 94. This is the same pattern found in the southern Brazil samples (16 repeats). However, none of the samples analyzed had the same number of repeats as the Brazilian samples. The number of repeats found in the US samples was closer to the number found for the northeastern Brazil samples. Previous studies have found a dominance of 2 to 9 repeats in outbreak ponds (Wongteerasupaya et al. 2003, Musthaq et al. 2006, Pradeep et al. 2008). However, the southern Brazil samples used in the present study originated from WSSV outbreaks and had 16 repeats. One possible explanation is that environmental conditions (lower temperatures and/or poor water quality) may have conferred a higher virulence to the Santa Catarina strain, since WSSV appears to replicate more efficiently at lower temperatures (Vidal et al. 2001) and this region of Brazil has lower average water temperatures than Bahia. Moreover, shrimp living in stressful environments are more susceptible to diseases.

The number of repeats found for ORF 125 was between 7 and 11. Previous studies found 5 to 8 (Dieu et al. 2004) and 2 to 14 repeats (Pradeep at al. 2008). The southern Brazil samples contained the same number of repeats (8) as the Nicaragua samples.

The samples from Texas and Mexico had the same number of repeats for ORF 75; however, the repeat pattern was different. Pradeep et al. (2008) found amplicons between 320 and $778 \mathrm{bp}$, with the majority yielding a $525 \mathrm{bp}$ amplicon. Dieu et al. (2004) found a variation of 5 to 21 repeats for this region.

Samples that have the same repeat pattern for a particular minisatellite may not have the same pattern for the other 2 minisatellites analyzed. For example, the south Brazil and Nicaragua samples had the same number of repeats for ORF 125 (8), but not for ORF 94 (14 for Nicaragua and 16 for Santa Catarina) and ORF 75 (8 for Nicaragua and 10 for Santa Catarina). This variation was also observed in other studies (Dieu et al. 2004, Pradeep et al. 2008).

ORF 23/24 was also analyzed. A 3000 bp amplicon was obtained for the Brazilian samples and after sequencing and comparison with WSSV-TW, a 11453 bp deletion was found. Marks et al. (2004) studied this region in 3 WSSV isolates: WSSV-TW, WSSVCN and WSSV-TH. WSSV-TW did not have this deletion, while WSSV-CN had a 1168 bp deletion and WSSV-TH had a 13210 bp deletion. The same authors suggested that this deletion could be due to homologous recombination or to genomic pressure on the virus to discard redundant sequences. Dieu et al. (2004) suggested that WSSV-TH branched from WSSV-TW and WSSV-CN and entered Vietnam by multiple introductions. Pradeep et al. (2008) found a $2400 \mathrm{bp}$ amplicon for this region when analyzing 
Indian samples. After comparing the sequence of this fragment with WSSV-TW, they found a 10970 bp deletion in the India samples in relation to WSSV-TW. The genome of WSSV-TW encodes a putative transposase, which is not present in WSSV-CN, WSSV-TH or WSSV-Vietnam (Dieu et al. 2004, Marks et al. 2004). The PCR for this region gives a $150 \mathrm{bp}$ product when the transposase is absent, a result also found in the Brazilian samples.

Despite the small numbers of samples analyzed, it was possible to find a repeat pattern in the molecular markers used, which was related to the geographic origins of the samples. These results show that the 3 ORFs analyzed (ORFs 94, 125 and 75) have a potential for use in epidemiological work with WSSV, particularly ORF 94 , which has a higher variation in repeat number. The variations in minisatellites could be useful in global epidemiological studies, while the SNPs observed within repeats can be useful in tracking the movement of a virus within more localized geographic areas. The PL sources of the farms analyzed in the present study could be studied with ORF 94 in order to determine if they have the same pattern of repeats found in the grow-out shrimp. The differences found between the 2 Brazilian regions may be due to multiple WSSV introductions into the country. Nonetheless, possible mutations of the viral genome due to environmental influences cannot be completely ruled out, and further studies are needed to test these different hypotheses.

Acknowledgements. The Gulf Coast Research Laboratory Consortium Marine Shrimp Farming Program, CSREES, USDA, grant no. 2002-38808-01345 supported this work. Secretaria Especial de Pesca (SEAP), Brazil, grant no. 352/2006 supported the work in Santa Catarina. Coordenação de Aperfeiçoamento de Pessoal de Nível Superior (CAPES) and the National Council for Scientific and Technological Development (CNPq), Ministry of Science and Technology, Brazil provided a Fellowship award to I.C.M. and T.P.D.A., respectively.

\section{LITERATURE CITED}

Baumgartner WA, Hawke JP, Bowles K, Varner PW, Hasson KW (2009) Primary diagnosis and surveillance of white spot syndrome virus in wild and farmed crawfish (Procambarus clarkii, $P$. zonangulus) in Louisiana, USA. Dis Aquat Org 85:15-22

Benson G (1999) Tandem repeats finder: a program to analyse DNA sequences. Nucleic Acids Res 27:573-580

Cai SL, Huang J, Wang CM, Song XL and others (1995) Epidemiological studies on the explosive epidemic disease of prawn in 1993-1994. J Fish China 19:112-117

> Dieu BTM, Marks H, Siebenga JJ, Goldbach RW, Zuidema D, Duong TP, Vlak JM (2004) Molecular epidemiology of white spot syndrome virus within Vietnam. J Gen Virol 85:3607-3618

Durand S, Lightner DV, Redman RM, Bonami JR (1997) Ultrastructure and morphogenesis of white spot syndrome baculovirus (WSSV). Dis Aquat Org 29:205-211
Flegel TW (1997) Major viral diseases of the black tiger prawn (Penaeus monodon) in Thailand. World J Microbiol Biotechnol 13:433-442

Hall TA (1999) BioEdit: a user-friendly biological sequence alignment editor and analysis program for Windows 95/98/NT. Nucleic Acids Symp Ser 41:95-98

$>\mathrm{He}$ N, Qin Q, Xu X (2005) Differential profile of genes expressed in hemocytes of White Spot Syndrome Virusresistant shrimp (Penaeus japonicus) by combining suppression subtractive hybridization and differential hybridization. Antiviral Res 66:39-45

Hoa TT, Hodgson RA, Oanh DT, Phuong NT, Preston NJ, Walker PJ (2005) Genotypic variations in tandem repeat DNA segments between ribonucleotide reductase subunit genes of white spot syndrome virus (WSSV) isolates from Vietnam. In: Diseases in Asian aquaculture V. Fish Health Sect, Asian Fish Soc, Manila, p 339-351

INFOFISH (1999) White spot syndrome spreads in Latin America. INFOFISH Int 5:37

Inouye $\mathrm{K}$, Miwa $\mathrm{S}$, Oseko $\mathrm{N}$, Nakano $\mathrm{H}$, Kimura $\mathrm{T}$, Momoyama K, Hiraoka M (1994) Mass mortalities of cultured Kuruma shrimp Penaeus japonicus in Japan in 1993: electron microscope evidence of the causative virus. Fish Pathol 29:149-158

Lightner DV (2005) Biosecurity in shrimp farming: pathogen exclusion through use of SPF stock and routine surveillance. J World Aquacult Soc 36:229-248

Lo CF, Leu JH, Ho CH, Chen CH and others (1996) Detection of baculovirus associated with white spot syndrome (WSBV) in penaeid shrimps using polymerase chain reaction. Dis Aquat Org 25:133-141

> Lo CF, Hsu HC, Tsai MF, Ho CH, Peng SE, Kou GH, Lightner DV (1999) Specific genomic DNA fragment analysis of different geographical clinical samples of shrimp white spot syndrome virus. Dis Aquat Org 35:175-185

> Marks H, Goldbach RW, Vlak JM, van Hulten MCW (2004) Genetic variation among isolates of white spot syndrome virus. Arch Virol 149:673-697

> Marks H, van Duijse JJ, Zuidema D, van Hulten MC, Vlak JM (2005) Fitness and virulence of an ancestral white spot syndrome virus isolate from shrimp. Virus Res 110:9-20

Mello GL, Farias AP (2007) Policultivo de tilápias e camarões marinhos. Os resultados das primeiras experiências em Laguna - SC. Panorama Aquicultura 17:42-47

> Musthaq SS, Sudhakaran R, Ahmed IVP, Balasubramanian G, Hameed SAS (2006) Variability in the tandem repetitive DNA sequence of white spot syndrome virus (WSSV) genome and suitability of VP28 gene to detect different isolates of WSSV from India. Aquaculture 256:34-41

> Nadala ECB Jr, Loh PC (1998) A comparative study of three different isolates of white spot virus. Dis Aquat Org 33:231-234

Nunan LM, Lightner DV (1997) Development of a nonradioactive gene probe by PCR for detection of white spot syndrome virus (WSSV). J Virol Methods 63:193-201

OIE (Office International des Epizooties/World Animal Health Organization) (2005a) Immediate notification report 6307. OIE, Paris

OIE (Office International des Epizooties/World Animal Health Organization) (2005b) White spot disease in Brazil. Follow-up report no. 1. Dis Inf 18:248-249

Pradeep B, Shekar M, Gudkovs N, Karunasagar I, Karunasagar I (2008) Genotyping of white spot syndrome virus prevalent in shrimp farms of India. Dis Aquat Org 78: 189-198

Seiffert WQ, Winckler S, Maggioni D (2005) A mancha branca em Santa Catarina. Rev Panorama Aqüicultura 87 
Shekar M, Karunasagar I, Karunasagar I (2005) A computer based identification of variable number tandem repeats in white spot syndrome virus genomes. Curr Sci 89: 882-887

van Hulten MCW, Witteveldt J, Peters S, Kloosterboer N and others (2001) The white spot syndrome virus DNA genome sequence. Virology 286:7-22

Vidal OM, Granja CB, Aranguren F, Broc JA, Salazar M (2001) A profound effect of hyperthermia on survival of Litopenaeus vannamei juveniles infected with the white spot syndrome virus. J World Aquacult Soc 32:364-372

Waikhom G, John KR, George MR, Jeyaseelan MJP (2006) Differential host passaging alters pathogenicity and induces genomic variation in white spot syndrome virus.

Editorial responsibility: Ken Hasson,

College Station, Texas, USA
Aquaculture 261:54-63

> Wang Q, Nunan LM, Lightner DV (2000) Identification of genomic variations among geographic isolates of white spot syndrome virus using restriction analysis and Southern blot hybridization. Dis Aquat Org 43:175-181

Wongteerasupaya C, Pungchai P, Withyachumnarnkul B, Boomsaeng V, Panyim S, Flegel TW, Walker PJ (2003) High variation in repetitive DNA fragment length for white spot syndrome virus (WSSV) isolates in Thailand. Dis Aquat Org 54:253-257

Yang F, He J, Lin XH, Li Q, Pan D, Zhang XB, Xu X (2001) Complete genome sequence of the shrimp white spot baciliform virus. J Virol 75:11811-11820

Submitted: March 30, 2009; Accepted: September 11, 2009 Proofs received from author(s): December 28, 2009 